\title{
Hospital medical staffing and vocational guidance: teaching hospital juniors' views
}

\author{
E B RENVOIZE, J D FEAR, S R W MOORE
}

The document Hospital Medical Staffing: Achieving a Balance, issued jointly by the Department of Health and Social Security and the Joint Consultants Committee in July 1986, proposes a series of measures aimed at bringing the hospital medical staffing structure into balance over the next 10 years.' This initiative has been endorsed by the Central Committee for Hospital Medical Services and the Hospital Junior Staff Committee. If the proposals are agreed implementation will start on 1 January 1987 and will result in major changes to the junior hospital doctors' career structure.

This study reports the views on the proposals of junior hospital medical staff working in a teaching district. As the document suggests that all senior house officers should receive formal career counselling the extent of previous vocational guidance received by junior doctors and their opinions on who should be responsible for this in the future was also assessed.

\section{Method}

A postal questionnaire and a photocopy of the proposals were sent to all 298 junior hospital doctors believed to be working in the Leeds Western Health Authority, their names, specialties, grades, and hospital addresses having been obtained from medical personnel. Doctors were asked to complete the questionnaire anonymously. The initial communication was sent out on 14 August 1986, followed by three reminders, and by 15 September 1986, 189 doctors (142 men and 47 women) had responded. Questions not answered on the returned questionnaires were classified, where possible, as "Don't know."

\section{Results}

The characteristics of the respondents are shown in table I. A majority were men, married, registrars or senior registrars, United Kingdom graduates, qualified for more than five years, intending to remain in hospital work, had a postgraduate qualification, and had not previously read the document Hospital Medical Staffing: Achieving a Balance. Response rates were lower in women and in house officers and senior house officers compared with registrars and senior registrars. Response rates by specialty varied from $27 \%$ in accident and emergency to $86 \%$ in psychiatry.

Table II shows the responses of junior doctors to the medical staffing proposals and related questions. A majority of doctors accepted the overall package but over a quarter were undecided. The proposals for senior house officers were acceptable, although respondents were evenly divided over agreement to undertake research at this level. There was general satisfaction with the regional registrar proposals but a large majority were in favour of part time regional registrar posts for doctors with domestic commitments. A majority were dissatisfied that United Kingdom graduates would not be able to apply for district registrar posts. A bare majority were agreeable to the establishment of the new nontraining intermediate level service post, but most were not themselves prepared to work permanently in such a grade.

Leeds Western Health Authority, Leeds LS1 3EX

E B RENVOIZE, MD, MRCPSYCH, registrar in community medicine

J D FEAR, MB, CHB, registrar in community medicine

S R W MOORE, MD, FFCM, district medical officer

Correspondence to: Dr Renvoize, Leeds General Infirmarv, Great George Street, Leeds LSI 3EX.
TABLE I-Characteristics of the respondents in Nos and percentage ${ }^{\star}$

\begin{tabular}{|c|c|c|c|}
\hline & No $\%$ & & $\mathrm{~N}(0, \%)$ \\
\hline \multicolumn{2}{|l|}{ Sex } & Postgraduatc qualifications & \\
\hline Male & $142(75)$ & Membership or fellowship & \\
\hline Female & $47(25)$ & None & $53(28)$ \\
\hline \multicolumn{2}{|l|}{ Marital status } & Part I & $+1(22)$ \\
\hline Single & $74(39)$ & Part II & $95(50)$ \\
\hline Married & $110(58)$ & Response rate by grade & \\
\hline Other & $5(3)$ & House officer & $(46$ \\
\hline \multicolumn{2}{|l|}{ Grade } & Senior house officer & 45 \\
\hline House officer & $19(10)$ & Registrar & $(69)$ \\
\hline Senior house officer & $40(21)$ & Senior registrar & $(82)$ \\
\hline Registrar & $63(33)$ & Response rate by specialty & \\
\hline Senior registrar & $65(35)$ & Psychiatry & $18 / 21(86)$ \\
\hline Unknowr & $2(1)$ & Anaesthetics & $18 / 23(78)$ \\
\hline \multicolumn{2}{|l|}{ Country of graduation } & Medicine & $62 / 84(74)$ \\
\hline UK graduate & $177(94)$ & Radiology & $10 / 14(71)$ \\
\hline Overseas graduate & 126 & Paediatrics & $711(64)$ \\
\hline \multirow{2}{*}{\multicolumn{2}{|c|}{ Years since qualification }} & Pathology & $1527(56)$ \\
\hline & & Radiotherapy/oncology & $916(56)$ \\
\hline Under 1 & $20(10)$ & Surgery & $4178(53$ \\
\hline $1-3$ & $27(14)$ & Obstetrics and gynaecology & $5 / 12+2)$ \\
\hline $3-5$ & $36\langle 19\rangle$ & Accident and emergency & $311(27)$ \\
\hline $5-10$ & $73(39)$ & Unknown & 1 \\
\hline $10+$ & $33(18)$ & Previously real the document & \\
\hline \multicolumn{2}{|c|}{ Intending to remain in hospital work } & $\begin{array}{l}\text { Previously read the document } \\
\text { Hospital Medical Staffing: }\end{array}$ & \\
\hline Yes & $15782)$ & Achieving a Balance & \\
\hline No & $16 \quad(9)$ & Yes & $68(36)$ \\
\hline Do not know & 16 & No & $121(64)$ \\
\hline
\end{tabular}

* Where two figures are given the first is the actual No of respondents and the second the total No in the specialty.

Most accepted the consultant proposals but almost half the respondents thought that the status of consultants would be reduced as a result $(47 \%)$. Seventy seven $(41 \%)$ thought that the proposals would have no effect; nine $(5 \%)$ thought that consultants' status would be enhanced; and $13(7 \%)$ were undecided. Over a quarter of junior doctors said that they would be prepared to participate in a first on call rota as a newly appointed consultant, and two thirds said that they would be prepared to undertake night work.

Only a minority believed that the implementation of the integrated medical staffing proposals would improve patient care, but a majority thought that junior doctor training would be improved.

The career preferences and vocational guidance responses of the respondents are summarised in table III. Most doctors were working in a specialty of first choice, but a majority said that they were willing to change specialty if they failed to make progress. Almost half had never received vocational guidance, and nearly two thirds wanted career counselling throughout their junior medical career. A consultant in the individual's chosen specialty and a panel of consultants were considered to be the most appropriate persons to give vocational guidance.

\section{Discussion}

As a result of the short time scale for comment on the proposals the survey was necessarily conducted over four weeks during the holiday season. It was also a time when many junior hospital doctors had recently changed posts and were likely to be preoccupied with their new jobs. The anonymity of the replies, designed to allow the junior doctor complete freedom to express his or her views, precluded personal follow up of the non-respondents and inevitably reduced our response rate. Also, disappointing response rates are generally obtained from anonymous surveys of junior doctors.? Better results are obtained when particular cohorts of medical staff 
are studied. ${ }^{3}$ In these circumstances the response rate of $63.4 \%$ in this study is satisfactory. As Leeds West is a teaching district these results may not, however, be representative of the views of junior hospital doctors working in non-teaching districts.

A majority of the respondents in this survey accepted the overall manpower initiative but with some reservations.

Our results suggest that the concept of the district registrar and the intermediate level service grade posts may need to be modified before they become credible to most junior medical staff; some provision for part time training at the regional registrar grade and extra provision for research posts in teaching districts may also be required.

\section{CONCERN OF RESPONDENTS}

Respondents were encouraged to write down their comments at the end of the questionnaire, and these frequently echoed the same themes. Concern was expressed that the proposals were not sufficiently comprehensive to solve the medical manpower problems of the National Health Service. Some were concerned that the registrar bottleneck would merely be moved down to senior house officer level, where junior doctors intending to become hospital consultants would be expected to do research despite their limited clinical experience in addition to studying for postgraduate qualifications. There was some disappointment that the proposals ignored the needs of vocational training of general practitioners and academic staff. Some were pessimistic that the measures by themselves would lead to an improvement in the standards of medical care in the United Kingdom.

Some junior medical staff (and consultants) seem to be confused about the relationship of the present senior house officer and

TABLE II-Responses to staffing proposals and related questions

\begin{tabular}{|c|c|c|c|}
\hline & \multicolumn{3}{|c|}{ No $(\%)$} \\
\hline & Yes & No & $\begin{array}{l}\text { Do not } \\
\text { know }\end{array}$ \\
\hline \multirow{5}{*}{$\begin{array}{l}\text { Acceptance of overall proposals } \\
\text { SHO proposals } \\
\text { Accept the idea: } \\
\text { of remaining at the proposed SHO grade for a longer } \\
\text { time, with appropriate remuneration } \\
\text { that general professional training be completed at the } \\
\text { SHO level } \\
\text { of undertaking research at SHO level } \\
\text { of retraining in another specialty at the new SHO } \\
\text { level, if advised }\end{array}$} & $96(51)$ & $41(22)$ & $52(27)$ \\
\hline & $140(74)$ & $33(18)$ & $16(8)$ \\
\hline & $152(81)$ & $27(14)$ & $10(5)$ \\
\hline & 8 & 8 & J) \\
\hline & $143(76)$ & $24(13)$ & $22(11)$ \\
\hline \multicolumn{4}{|l|}{ Registrar proposals } \\
\hline $\begin{array}{l}\text { Satisfied with the pro } \\
\text { Satisfied with the ide }\end{array}$ & $161(85)$ & $17(9)$ & $11(6)$ \\
\hline $\begin{array}{l}\text { increased competition for regional registrar posts } \\
\text { the eventual merging of the present registrar and senior }\end{array}$ & $84(44)$ & $66(35)$ & $39(21)$ \\
\hline & $111(59)$ & $56(30)$ & $22(11)$ \\
\hline region & $113(60)$ & $21(11)$ & $55(29)$ \\
\hline regional reg & 177( & & $6(3)$ \\
\hline $\begin{array}{l}\text { Should there be part time regional registrar posts? } \\
\text { Satisfied that UK graduates will be unable to apply for }\end{array}$ & $151(80)$ & $36(19)$ & $2(1)$ \\
\hline district registrar posts & $32(17)$ & $129(68)$ & $28(15)$ \\
\hline \multicolumn{4}{|l|}{$\begin{array}{l}\text { Intermediate level service grade proposals } \\
\text { Satisfied with the idea of: }\end{array}$} \\
\hline $\begin{array}{l}\text { the new non-training intermediate level service grade } \\
\text { working permanently in such a grade } \\
\text { working in this grade on a sessional basis } \\
\text { working for the responsible consultant in this grade }\end{array}$ & $\begin{array}{l}86(45) \\
38(20) \\
91(48) \\
66(35)\end{array}$ & $\begin{array}{r}79(42) \\
124(66) \\
70(37) \\
81(43)\end{array}$ & $\begin{array}{l}24(13) \\
27(14) \\
28(15) \\
42(22)\end{array}$ \\
\hline \multicolumn{4}{|l|}{$\begin{array}{l}\text { Consultant proposals as they might affect current junior } \\
\text { medical staff }\end{array}$} \\
\hline $\begin{array}{l}\text { Satisfied with the proposed expansion of consultant posts } \\
\text { with fewer junior staff }\end{array}$ & $107(57)$ & $53(28)$ & $29(15)$ \\
\hline $\begin{array}{l}\text { arrangements, agreeable to: } \\
\text { being included in a first on-call rota } \\
\text { undertaking night work } \\
\text { working without a senior registrar } \\
\text { working without a registrar } \\
\text { being responsible for the direct supervision and training }\end{array}$ & $\begin{array}{r}53(28) \\
124(66) \\
155(82) \\
64(34)\end{array}$ & $\begin{array}{l}117(62) \\
42(22) \\
14(7) \\
99(52)\end{array}$ & $\begin{array}{l}19(10) \\
23(12) \\
20(11) \\
26(14)\end{array}$ \\
\hline of junior medical staff & $174(92)$ & $2(1)$ & $13(7)$ \\
\hline \multicolumn{4}{|l|}{ Effect of proposals on patient care and junior doctor training } \\
\hline & 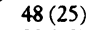 & $73(39)$ & \\
\hline Improve ju & $80(42)$ & 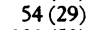 & $55(29)$ \\
\hline Reduce the length of junior doctor training & $32(17)$ & $101(53)$ & $56(30)$ \\
\hline
\end{tabular}

TABLE III-Career preferences and vocational guidance responses

\begin{tabular}{|c|c|c|c|}
\hline & No(\%) & & No $(\%)$ \\
\hline \multicolumn{2}{|c|}{ Working in specialty of first choice } & \multicolumn{2}{|c|}{ When should vocational guidance be given? } \\
\hline Yes & $162(86)$ & Undergraduate & $36(19)$ \\
\hline No & $27(14)$ & House officer & $41(22)$ \\
\hline \multicolumn{2}{|c|}{ Intention to remain in this specialty } & Senior house officer & $38(20)$ \\
\hline Yes & $140(74)$ & Registrar & $15(8)$ \\
\hline & 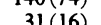 & Senior registrar & $3(2)$ \\
\hline & & & $119(63)$ \\
\hline \multirow{2}{*}{\multicolumn{2}{|c|}{$\begin{array}{l}\text { Willingness to change specialty if failure } \\
\text { to make progress in current specialty }\end{array}$}} & Never & $3(2)$ \\
\hline & & \multicolumn{2}{|l|}{$\begin{array}{l}\text { Who is best able to give vocational } \\
\text { guidance? }\end{array}$} \\
\hline Yes & $100(53)$ & A consultant in chosen specialty & $85(45)$ \\
\hline No & $74(39)$ & A panel of consultants & $63(33)$ \\
\hline Donot know & $15(8)$ & Postgraduate dean & $39(21)$ \\
\hline \multicolumn{2}{|c|}{$\begin{array}{l}\text { Previous receipt of vocational guidance at } \\
\text { the following grades: }\end{array}$} & $\begin{array}{l}\text { Present consultant } \\
\text { Regional adviser }\end{array}$ & $\begin{array}{l}36(19) \\
33(18)\end{array}$ \\
\hline Undergraduate & $41(22)$ & Clinical tutor & $31(16)$ \\
\hline House officer & $22(12)$ & Academic staff & $14(7)$ \\
\hline Senior house officer & $41(22)$ & Medical personnel & $9(5)$ \\
\hline Registrar & $41(22)$ & Dean of medical school & $6(3)$ \\
\hline egistrar & $10(5)$ & District medical officer & $0(0)$ \\
\hline Never & $88(47)$ & None of these & $3(2)$ \\
\hline
\end{tabular}

registrar posts to the proposed new posts of the same name; iN adoption of different titles for these training grades might help to $\omega$ resolve this ambiguity. Fears were also expressed that the failure of of the royal colleges to approve training in non-teaching health of districts would thwart the proposal to allow at least one regional : registrar post in each of the acute specialties in each district.

The finding that almost half the respondents, including many $\omega$ with postgraduate qualifications, had never received vocational 윽 guidance is surprising, but there are no grounds to think that junior $N$ doctors working in Leeds West are unusual in this respect.

Career counselling is far too important to be left to the $\stackrel{\odot}{\odot}$ postgraduate stage, and a more dynamic approach to vocational guidance is required at the undergraduate level. This requires the development of existing departments of postgraduate medical $\vec{\varphi}$ education and an extension of their role and influence into the undergraduate curriculum, thus allowing medical students to be exposed to a much wider range of career possibilities than is currently the case. The present oversubscription of the acute specialties of medicine and surgery does not necessarily indicate the innate unpopularity of other specialties but may reflect current $\frac{\mathrm{D}}{\mathrm{Q}}$ medical school selection procedures and undergraduate training. The wide variation in the career preferences of newly qualified doctors for individual specialties at different medical schools throughout the United Kingdom supports this argument. ${ }^{4}$

Similarly, a more positive approach to vocational guidance at the postgraduate stage is needed. It is clear from our study that many junior doctors are willing to change specialty if necessary, so that the proposal to give all senior house officers formal career counselling shortly after entry into the grade and regularly thereafter is a logical development.

Finally, who should give this vocational guidance? Only one fifth of respondents considered that their present consultant was best $\mathrm{O}$ able to give advice; another consultant in the junior doctors' $\mathrm{N}$ specialty was the most popular choice.

Whatever arrangements are made to give career counselling, and $\frac{D}{2}$ this may vary from place to place, the postgraduate tutor or similar figure in each health district could, with a suitable interest, time, 요 and training, have a useful coordinating and counselling role in $\omega$ conjunction with the regional postgraduate dean.

We should like to thank the doctors who completed the questionnaire and Mrs Jean Arundale for secretarial help.

\section{References}

1 Department of Health and Social Security, Joint Consultants Committee, chairmen of regional health authorities. Hospital medical staffing: achieoing a balance. London: DHSS, 1986.

2 Cartwright A. Health surveys in practice and in potential. London: King's Fund, 1983.

3 Parkhouse J, Campbell MG. What do young doctors think of their training and themselves? Of BrMed f 1984;288:1976-7.

4 Ellin DJ, Parkhouse HF, Parkhouse J. Career preferences of doctors qualifying in the United

Kingdom in 1983. Health Trends 1986;18:59-63.

(Accepted 26 September 1986) 